\title{
Drops in the bucket? A review of onshore responses to Somali piracy
}

\author{
Christian Bueger
}

Received: 12 December 2011 / Accepted: 6 March 2012 /Published online: 20 March 2012

(C) World Maritime University 2012

\begin{abstract}
That piracy needs to be addressed onshore is a widely shared assumption. While the majority of counter-piracy measures focus on the sea, a number of onshore counter-piracy initiatives have been launched. We can observe the seeds of an alternative land-based policy approach. One set of land-based programs aims at strengthening the legal and security state apparatus to better deter and punish pirates. The other set of programs aims at addressing local populations on regional, clan or village levels. Such projects aim at increasing surveillance, sensitizing populations for the consequences of piracy, and providing rehabilitation or alternative livelihood opportunities. In this article, I review the latter type of projects and discuss the promises and difficulties of addressing piracy by such measures. I discuss five major problems: knowledge problems, implementation problems, counterintuitive consequences, tensions towards other parts of counter-piracy strategy, and the securitization of aid.
\end{abstract}

Keywords Piracy $\cdot$ Somalia $\cdot$ Onshore solutions $\cdot$ Developmental responses $\cdot$ Security development nexus

\section{Introduction: addressing piracy onshore}

"Piracy can be only fought on land." "Piracy needs to be tackled onshore." These statements reflect a common wisdom in counter-piracy discourse: piracy is a problem that needs to be addressed onshore. Yet, if we investigate the major measures currently implemented to counter Somali piracy, we find that the majority of

\footnotetext{
C. Bueger $(\bowtie)$

Department of Politics, School of European Studies, Cardiff University, 65-68 Park Place,

Cardiff CF10 3AS Wales, UK

e-mail: buegercm@cf.ac.uk
} 
counter-piracy activities are maritime solutions. Naval patrols, transit corridors, escort programs, the hardening of vessels, or the employment of private guards on board vessels are measures that focus on the sea not on the land. ${ }^{1}$ Contrary to the common wisdom, and despite growing criticism towards current policies, the majority of activities addressing Somali piracy are maritime measures.

Yet, with the growing calls to fight piracy on land, more emphasis is being placed on finding onshore answers to Somali piracy. Indeed a number of onshore initiatives and pilot projects have been launched more recently. Two types of onshore projects can be distinguished. Firstly, a range of programs relies on a law enforcement and policing model. They aim at improving legal and police capacities in Somalia and the wider East African region. These projects include security sector reforms, such as, strengthening surveillance and coast guard capabilities. Or they aim at improving the legal capacities to prosecute and sentence piracy suspects and conduct legal training, develop prison capacities, victim support programs, or evidence collection capabilities. Secondly, a range of projects relies on a development model in aiming at addressing the root causes of piracy. They see solutions to piracy in development programs. Such projects aim at preventing piracy through community based rehabilitation, reintegration, or preventive programs, awareness campaigns or alternative livelihood projects. Rather than strengthening state capacities such projects address local populations directly through cooperation with local authorities, such as, village elders and collaboration with local NGOs or local economic actors.

In this article I review current projects that aim at addressing piracy onshore. My main focus is on the second type of projects which foreground the importance of development assistance. The majority of these projects have so far hardly achieved any academic or public attention. If the common wisdom that piracy needs to be tackled onshore is taken seriously, then it is an important task to evaluate the contributions of onshore, development-oriented projects to counter piracy. What are the promises and perils of the projects that present themselves as an alternative approach to law enforcement and policing? Addressing piracy by developmental, preventive means is a difficult affair. Not only is the efficiency of such projects contested, but fears abound that they might even reinforce the piracy business. As I will show in the following, there are severe problems and risks associated with these projects and the direct impact of them has been limited so far. However, many of the so-called root causes of piracy can only be addressed through such programs. It is hence an imperative to carefully review these projects and consider how more investments can be meaningfully made.

The article is structured in the following way. I firstly provide a brief overview of the kinds of onshore projects and discuss the conceptual differences between security and law-oriented projects and developmental projects. Secondly, I review current projects in Somalia in greater detail. Thirdly, I discuss the main problems that arise in implementing these projects. I focus on general hindrances to invest in such projects and investigate the trade-offs and dilemmas that arise between development projects and other objectives and counter-piracy measures.

\footnotetext{
${ }^{1}$ For overviews of these measures see for instance Bahadur (2011), Bueger (2012), Geiss and Petrig (2011), or Kraska (2011).
} 


\section{Approaches to counter-piracy: an overview}

The problem of piracy off the coast of Somalia, in the Gulf of Aden and in the wider Indian Ocean has led to an array of international activities. Indeed a complex assemblage of various practices aims at addressing piracy (Bueger and Stockbruegger 2012). While this is not the place to give a comprehensive overview of these overlapping and sometimes contradictory practices, ${ }^{2}$ a meaningful brief overview can be given in addressing two questions: firstly, where do the activities take place? Secondly, what type of general approach is taken, or phrased otherwise, how is piracy addressed?

In answering the first question, we can distinguish between practice at sea and at land. We can further differentiate the land-based practices by whether they are conducted in Somalia or the wider region (including states, such as, Kenya, Seychelles, Djibouti, or Pakistan). The second question leads us to at least four different types of general approaches which treat piracy as a different type of problem (Bueger 2012). The first is the security approach. It treats piracy to be an "existential threat" to national and international security. Piracy is considered to be addressed by primarily military means and the use of violence. The second approach treats piracy to be primarily a deviant form of behavior that requires to be punished and be addressed by law enforcement operations. Piracy is considered as a crime which requires police responses. A third approach views piracy as a primarily technical problem which can be addressed through adequate defensive measures, such as, optimized transit corridors and optimal vessel hardening to prevent the success of a piracy attack. A fourth approach sees piracy mainly as a development problem. Piracy is treated as symptom of underdevelopment, that is, a problem of state failure, weak governance, corruption, poverty, or unemployment. Seen as a development problem, piracy is approached by means of development assistance or the repertoire of peacebuilding measures.

Seen from the backdrop of this categorization, the majority of onshore projects fall into the former two categories of security and law enforcement. A large number of onshore projects directly or indirectly supports the naval operations in the Gulf of Aden. Projects in the frame of the United Nations Office of Drugs and Crime (UNODC) counter-piracy program (UNODC 2011a, b) or the Djibouti process organized by the International Maritime Organization (IMO 2011) aim at improving law enforcement in the East African coast. They either develop regional law facilities (courts, prisons, legal training) in countries including Kenya, Tanzania, Yemen, or the Seychelles and in the Somali semi-autonomous regions of Puntland and Somaliland. Or they improve the security governance in the region through optimizing coast guard facilities and training or through strengthened information sharing and surveillance. Such projects operate on the assumption that countering piracy requires a strengthened legal and security state apparatus. They are partially reactive in that they develop measures for the case that piracy suspects have been arrested. But they are also preventive, in the sense that arrest, prosecution, and imprisonment are considered to be viable deterrents which should be enforced by state governments.

\footnotetext{
${ }^{2}$ See notably Bueger (2012), Bueger and Stockbruegger (2012), and Kraska (2011) for a discussion of the interplay between different counter-piracy practices.
} 
Weak security governance is, however, only one of the factors that allows piracy to thrive. As the literature has shown, cultural acceptability, domination of the populace, and economic incentives induced by poverty and the lack of income and employment opportunities are others. ${ }^{3}$ It is exactly these issues that alternative approaches aim at addressing and thereby complement the marine deterrence and law enforcement counter-piracy program. With the goals of reducing the legitimacy of piracy in Somalia and providing alternative opportunities for a decent living, the lines of counter-piracy policy and the wider development, peace building, and state building policies of the international community in Somalia become blurred. After all, reducing poverty is one of the main goals of development policy. A clear line between counter-piracy policy and the general development policy towards Somalia cannot be drawn. Yet, a number of projects have been initiated that want to directly target the problem of piracy.

In the following, I discuss these projects. I suggest that it is useful to differentiate between four different ways in which projects use a developmental repertoire of measures to address piracy. These are firstly, projects that want to prevent piracy through surveillance; secondly, projects that conduct prevention campaigns; thirdly, projects conducting rehabilitation and reintegration with former pirates, and, fourthly, projects which want to offer alternative livelihood opportunities. In what follows, I discuss current projects which follow these four lines. I proceed in outlining some of the dilemmas such alternative counter-piracy approaches are facing.

\section{Prevention through surveillance: "we know what you are doing"}

A first set of projects aims at furthering land-based surveillance of potential piracy activities. These projects mainly remain within a law enforcement paradigm; they aim at reducing the response time to potential piracy operations and allow for better early warning information for the shipping industry (concerning potential mother ships and areas in which pirate groups operate). The collection of information on piracy activities has, however, also additional benefits. It firstly integrates local villages and coastal communities in counter-piracy policy. Through contacting information collecting points, local communities can de facto do something against pirates. They can participate in counter-piracy campaigns. Hence, in the longer run information collection provides a pathway of cooperating with local communities. Increased surveillance is, secondly, a deterrent. If pirate gangs recognize that they are being watched, they might be more reluctant to carry out operations.

Strengthening surveillance and collecting local information is one of the pillars of the IMO organized Djibouti Process. However, even non-governmental organizations (NGOs) inside Somalia collect piracy information. One instance is the NGO "Peacelink." Based in Mogadishu, and with offices across south central Somalia since May 2011, Peacelink conducts onshore monitoring and surveillance of piracy activities (Peacelink 2011). To some degree also, local media outlets and information services, such as, Somalia Report provide such surveillance services.

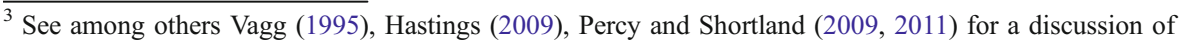
these factors.
} 
In summary, apart from contributing to a law enforcement model, the surveillance approach can potentially strengthen the links to coastal communities, provides potential seeds of cooperation between internationals and locals and encourages local populations that they can act meaningfully against piracy. Strengthening such partnerships is important in the longer run and can also enable mutual confidence building. The impact of these projects on piracy is, however, indirect. Yet we can reasonably expect that they are one tool of undermining local support for piracy.

\section{Cultural and moral prevention campaigns: "don't become a pirate!"}

A second approach is constituted by public campaigns directed at potential pirates. Such campaigns aim at raising awareness that piracy is illegitimate and that participating in it has direct consequences. In military language, public campaigns aim at winning the "hearts and minds" of potential pirates and convincing them not to participate in piracy operations. Seen from the perspective of deterrence theory, they constitute a form of "deterrence by denial" (Knopf 2010: 10). "In contrast to deterrence by punishment, which threatens to inflict costs through retaliation after an attack, denial strategies aim to dissuade a potential attacker by convincing them that the effort will not succeed and they will be denied the benefits they hope to obtain" (Knopf 2010: 10).

Several initiatives follow such an approach and have implemented public information campaigns which disseminate the message that participating in piracy operations may have severe consequences, including, imprisonment or death and that piracy operations have a high risk of failure. They also propagate that piracy is immoral and conflicts with the local culture and traditions. Several kinds of communication channels are used to reach Somalis, including radio and TV broadcasting, events in villages, or handing out leaflets and other publication materials.

Designing and implementing public awareness campaigns was initially on the agenda of the UN Contact Group to Counter Piracy off the Coast of Somalia, the main governance vehicle organizing international counter-piracy policy. The Contact Group's Working Group 4 aimed at deliberating possibilities for information campaigns. However, the working group produced little visible or tangible outcomes in terms of concrete projects. Nonetheless, the mere existence of the working group is important to keep the public awareness approach on the international agenda. Indeed, a number of public awareness campaigns were organized by other actors.

Arguably, the public awareness approach was spearheaded by the Government of Puntland. Three months after his election in January 2009, president Abdirahman Farole launched a grassroots counter-piracy program spearheaded by Sheikh Abdulkhadar Nur Farah (Bahadur 2011: 111). "In what was described as an "educational and spiritual campaign" to discourage new recruits, the government offered total amnesty to any former pirate agreeing to give up the trade" (Bahadur 2011: 111). As Garoweonline (2011) reported on the campaign:

"All mosques in Garowe focused Friday's weekly sermon on the negative impact of piracy on the local community. The preacher at Garowe's Sahaba Mosque spoke both in Somali and Arabic languages, citing Islamic sources that 
explicitly prohibit 'criminal acts like piracy.' 'All forms of roadblocks are haram [prohibited] in Islam. Our religion instructs us to give safe passage to all travelers, by sea or by land,' the preacher told hundreds of congregants. He spoke in detail about the many social problems pirates have brought to Puntland, namely increase in the sale and consumption of alcohol, the use of the narcotic drug khat and other un-Islamic acts such as adultery and fornication. The preacher offered three stories as typical examples of pirates' negative social impact on local communities. In one example, he strongly warned against the spread of HIV/AIDS in the community as 'prostitutes from everywhere' have been drawn to Puntland by the pirates' ransom money."

The campaign launched in April 2009, however, faded out quickly partially due to the lack of funding. This gap was, however, filled by the NGO Norwegian Church Aid. Contemporary public awareness campaigns are run by NATO, by the Norwegian Church Aid, and in October 2011, the United Nations Office of Drugs and Crime (UNODC) launched a major new public awareness program.

NATO conducts an awareness project which is constituted by the broadcast of counter piracy messages (NATO 2011). The message is broadcasted in English and Somali on Somali radio stations. The message encourages "Somalia people to stay out of piracy business" (NATO 2011). The broadcast informs about the counterpiracy operations carried out in the Gulf and warns about the dangers of piracy in stressing that many pirates "will stay in prison for years instead of being with their families," that the number of pirates in jail continuously raise, and that "pirates are putting their lives in danger every time they sail armed with intent to hijack" (NATO 2011). The problem with this broadcast, which starts with the line "This is a message from NATO..." (NATO 2011), is that it is easily perceived as propaganda from an outside military organization. Broadcasting radio messages or dropping leaflets is part of NATO's conventional repertoire of war faring and counter insurgency. ${ }^{4}$ NATO's approach highlights the risk that if counter-piracy messages are understood as outside propaganda and are not sufficiently sensitive to the local context, that they may have little effect. NATO, however, here most likely takes a "better than nothing" approach. Broadcasting might have some positive benefits at relatively low costs. However, if we consider how a commercial we hear on our most favorite radio station actually affects us in our daily life, the effects of this approach may be evaluated as rather marginal and it is doubtful that the campaign reaches prospective pirates. Yet, NATO's broadcasting campaign should be seen in the light of its larger approach of increasingly cooperating and communicating with village elders (NATO 2010).

Arguably, the more valuable approach is the one taken by NGOs, since they embed the broadcasting of messages in wider projects of working with villages and clans and using local authorities to spread the counter-piracy message. On of such more extended projects is the one implemented by Norwegian Church Aid (NCA). It runs in cooperation with the Government of Puntland' s Ministry of Justice, Religious Affairs and Rehabilitation, a Norwegian insurance company, the Norwegian Shipowners Association and the Norwegian Ministry of Foreign Affairs a project titled "Anti-piracy

\footnotetext{
$\overline{{ }^{4} \text { See for instance the campaigns }}$ NATO launched in Afghanistan (U.S. Airforce 2007)
} 
measures through awareness raising, training and alternative livelihood in Puntland". The three year project has a budget of 850.000 Euros, and "aims to promote awareness of the negative effects of piracy as well as provide improved livelihoods for 1,200 ex-pirates" (SSRRC 2010). NCA works in Puntland coastal areas and combines the awareness campaign with a rehabilitation and re-integration project (reviewed in the next section).

NCA's approach is centered on the collaboration with village authorities, clan elders and religious leaders. Following a 2010 evaluation of NCA activities conducted by Acacia Consultants, the awareness campaign has the following components:

- "Capacity development of religious leaders as key duty bearers to use religion to demonstrate the ills of piracy.

- Conducting anti-piracy campaigns and rallies,

- Use of Friday 'juma' sermons in Mosques across the state to pass structured messages on anti-piracy,

- Holding workshops with key stakeholders including community institutions to create awareness on anti-piracy,

- Use of print, radio and audio media channels to pass messages to youths, duty bearers, active pirates and entire communities,

- Organizing inter-school games tournaments, specifically targeting youths and communities in the school environs to pass anti-piracy messages" (Acacia and NCA 2010: 25)

NCA primarily works with religious leaders', elders' and women's groups. Women's groups such as the Somalia Women Vision (SWV) of Puntland carry out anti-piracy advocacy through training workshops and public fora. Following the evaluation,

"SWV managed to create awareness to 90 youth who were in piracy business before. They had targeted 5 villages drawn from Garowe, Bosaso, Bargal, Ely and Pandar Mbalya which are the hotspots for piracy activities. In Garowe, over 100, mainly pirates, participated in the public fora." (Acacia and NCA 2010: 26).

A second core group is religious leaders. The interviews with religious leaders conducted in the frame of the evaluation revealed that

"religious leaders confirmed that the NCA trained them on effective communication skills so as they are able to dialogue and pass the correct message amicably. Besides holding public address forums in the villages which are mainly affected, they have also included issues on piracy in preaching in the mosques." (Acacia and NCA 2010:26).

In their work, NCA uses and disseminates leaflets (NCA 2010). The leaflet has as its core messages that "piracy money is unlawful in Islam," and that "piracy leads to prison." The inside of the flyer lists reasons why not to engage in piracy ("piracy is human destruction," "piracy spreads HIV/AIDS," "be careful about piracy it leads to hell," or "ransom can't help you after death") as well as advice ("if you are lost, ask 
the religious leaders") and calls for engagement ("Be an adviser to everyone about piracy"). The main undertone of the flyer is clearly religious, with references being made to Islam (unlawful in Islam, leads to hell, ask religious leaders).

The evaluation comes to the conclusion that the campaigns have been a relative success, but that they need to be significantly expanded. As a core success, the evaluation highlights that " 3 villages have declared zero tolerance to the piracy activities and their villages declared a no-go-zone for pirates. In a matter of time, 3 other villages are expected to make similar declaration." (Arcadia and NCA 2010:26). However, it is also stressed that the "efforts have completely converted the lifestyle of six pirates who have quit piracy" (Acacia and NCA 2010: 26), which is everything but an impressive number. Also, only three major rallies have been conducted, the number of people reached remains limited as indicated by the numbers listed above (e.g., the 100 people reached by SWV).

The program launched by UNODC in late 2011 promises to significantly extend the campaigning work of NCA. The project is an 18-month, US\$1.1 million project mainly funded by the UK government and the One Earth Future Foundation. The project, which is currently in its first phase partners with former pirate leader and financier "Boyah" ${ }^{5}$ and the Farole government to launch a large-scale multimedia campaign that consists of the following elements:

- Broadcasting local success stories via radio, TV, SMS, and print media

- A radio series on two boys turning to piracy

- A writing and song-writing competition

- Comic strips in local newspapers

- Caravans of elders, clerics, and women's groups. The caravan includes a big-screen television on the back of a pick-up truck which broadcasts anti-piracy messages and is supported by artists.

- Work with the diaspora

- "Celebrity appearances" from the Somali diaspora

- Travel by Farole to visit pirates in custody worldwide to disseminate the anti-piracy message to the diaspora globally

The larger scale project of UNODC promises to continue the work of NCA and the multimedia campaign most likely will also reach other districts beyond those the NCA work could cover. It is moreover interesting since it attempts to integrate also the diaspora in the counter-piracy work.

In summary, the awareness approach is important to sensitize locals and especially youths to the fact that piracy has consequences and contains significant risks. Without a doubt, the approach taken by NCA and UNODC is a more promising one then NATO's limited broadcasting strategy. Yet, the NCA and even more the extended UNODC approach is resource intensive, requires a deep immersion in local affairs. A deeper rooted problem is, however, the moral approach taken by NCA, UNODC as well as NATO. The approach is backed up by an NCA-sponsored survey, in which $85 \%$ of respondents suggested that working with religious leaders is the most promising strategy (Rashid 2009). Moralizing piracy and casting the problem in

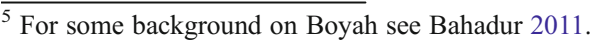


religious terms, however, may not necessarily reach especially the youths supportive of piracy. These might be more interested in the alternative lifestyle and the social prestige of being a pirate, rather than in complying with religion. Also, pointing to the hazards of piracy does not necessarily have to be a success strategy. As is well-known from displaying "smoking kills" messages on cigarette packages, knowing the consequences does not necessarily or directly lead to a change in risk-taking behavior. Moreover, and maybe most problematically, the campaigns face a significant conceptual gap, since they do not engage so far with the core justifications of pirates (Bueger et al 2011). Any enterprise requires a justification which projects it as valuable and legitimate. The same is true for piracy. Pirates justify their operations by claiming to defend their homeland and coastlines against foreign vessels, over-fishing, and toxic dumping. As deterrence theorists have highlighted successful campaigns also conduct de-legitimization (Knopf 2010). Such an approach aims at demonstrating that the justifications for piracy are illegitimate, that piracy cannot by legitimized by a good cause, such as, protecting the homeland. Since any criminal activity requires legitimation, undermining justification patterns, may make it more difficult to piracy financiers to recruit and to find local support. Finally, former and prospective pirates require hope, that is, alternative perspectives of a decent living. It is this objective that the third approach to onshore counter-piracy wants to achieve.

\section{Rehabilitation and reintegration: "don't return to piracy!"}

The public awareness campaign from the NCA project is combined with a third approach, the attempt to rehabilitate and reintegrate former pirates. Individuals, who already have participated in a piracy operation, have "valuable" operational experience and are hence likely to be re-employed. The majority of pirates do more than one tour, not the least because the piracy lifestyle offers some pleasures and certain social prestige, and the relatively remote ransom cash the average pirate foot soldier earns (Bahadur (2011: 227) estimates sums between US\$12.000 and US\$42.000 depending on the position within the operation) runs out quickly. Moreover, opting out of piracy is not necessarily easy. Many families, subclans and clans reject piracy as illegitimate and immoral business. The reformed pirate is hence not necessarily welcomed with open arms in his families or villages. It is difficult to return to the life the pirate gave up when joining pirate operations and as a former pirate it might become even more difficult to find other employment or sources of income.

Such problems are well-known to the international community, since they are an overall post-civil war phenomenon. Turning former combatants after civil wars to citizens is an ongoing challenge in many post-war, peacebuilding contexts (Knight 2008). The response to the problem by the international community are so-called Disarmament, Demobilization and Re-integration Programs (usually acronymized as DDR). Although pirates are not combatants and piracy is not war, the program initiated by NCA might well be understood as DDR-type programs, since it deals with similar problems (SSRRC 2010).

NCA's program consists of two pillars, firstly, vocational training and, secondly, business skill training and start off grants. Vocational training is conducted in the vocational training centers in Garowe or Galkayo, and trainees receive training on 
welding, masonry, carpentry, basic electrical engineering, mechanics or driving. Students are taught in a group of 50, and graduate after 3 months courses in a "colorful ceremony" (Abdi 2011a). Upon graduation, participants are equipped with a toolbox to make them ready for business. Following the NCA evaluation, NCA has entered into an agreement with the Government Vocational Training Center to train 600 former pirates. The first group of trainees was graduated in autumn 2010. In the second pillar, training in enterprise development is conducted by the local NGO, Somali Relief and Development Organization (SORDO) in Garowe. In this training, former pirates acquire business skills and are provided with start off capital of US $\$ 300$. In autumn 2010, 25 former pirates were in training, with 50 additional to receive training.

Participants to the program have to go through a selection process, which involves clan elders as well as governmental representatives. ${ }^{6}$ Applicants to the program have to fulfill various criteria. They have to be from a coastal region, they must be former pirates or have been involved in piracy, the candidate has to sign his commitment and swear to Allah; he should be aged between 15 and 45 . Each candidate requires a guarantor from his family or clan to make sure that the candidate behaves in a proper way, to ensure against potential damages caused and also to validate that the candidate de facto has been involved in piracy. The project strives to reach a balance between different clans and also aims at considering minority clans. In the selection process, NCA cooperates closely with the Puntland Ministry of Education. The ministry has also the final word on selecting a candidate. The selection procedure is one of the most sensitive issues of the program. Firstly, because participation in the program involves some form of amnesty and, secondly, as further discussed below, giving an individual a opportunity for training (and a start-up grant) in a war shattered country such as Somalia, might be considered as a de facto reward for piracy.

The NCA evaluation sees the main problems in the lack of effective capacities for conducting training (facilities and trainers). The success of the program is so far unclear. Reportedly a handful of former pirates has already found employment or started their own business. One needs to await the next evaluation report to assess the efficacy of the project. Although an innovative project, it remains in an "embryonic" state and requires further development (Acacia and NCA 2010: VIII).

\section{Alternative livelihood and other development projects: "do something better with your life!"}

A fourth approach centers on the idea that Somali requires "alternatives" to piracy, that is, alternative sources of income and alternative professional identities. This approach differs from the former as it is not centered on former pirates, but on prospective ones. The assumption is that after decades of civil war, many Somali are trained in the use of weapons and military tactics but have little other training. Hence, their choice is largely one of joining militias and governmental armed forces or engaging in piracy, while the trade-off is that piracy promises higher earnings (at,

\footnotetext{
$\overline{{ }^{6} \text { Compare Interview conducted }}$ by Jan Stockbruegger with a representative of NCA, Nairobi, Kenya October 2011.
} 
in some cases, a higher risk). While it is tempting to join a piracy gang, it is not necessarily easy. Employment is competitive (rumors even suggest the existence of a waiting list for joining piracy operations). Yet, people with some seafaring skills and experience (that is often fishing experience) will find a pirate tour more easily. A former pirate, who participated in the NCA program, was cited by Somalia Report as saying that "they recruit indiscriminately, as long as the recruits fulfill the following requirements: be a sea expert, be a proficient swimmer, be strong" (Abdi 2011b).

All this makes people from coastal towns, such as fishermen, more vulnerable to piracy. Yet, a typical piracy operation not only consists of sea-going hijackers but also entails jobs as watchmen, guardians, cooks, accountants, translators, or suppliers, which do not necessarily require seafaring experience (Bahadur 2011). The goal of alternative livelihood programs is to make individuals (notably those with seafaring experience) aware that they have a choice and that they can choose an alternative to the piracy professions. Providing such alternatives requires major development assistance to the Somali economy and infrastructure. Hence, in the realm of this approach, the lines between more general development assistance and counter-piracy become blurred. Indeed, the main difference between a typical development assistance project and a counter-piracy project is the emphasis they put on coastal villages and communities, as the spaces where individuals are more vulnerable to piracy and recruitment takes place.

Somalia remains in a difficult economic situation, and hence alternatives cannot be easily created or offered. A number of proposals have been made on which issues alternative livelihood projects may focus. Yet, projects that work within an alternative livelihood approach to address piracy remain in the planning stage.

As one of the first proposals, the 2009 NCA survey with local actors identified four core areas on which alternative livelihood projects should concentrate (Rashid 2009: 21): the improvement of fishery through the provision of fishing gear, the improvement of small scale business through business training and the provision of micro credit, artisanal crafts' training, and livestock improvement projects for pastoralists.

The main funding device for counter-piracy projects, the Trust Fund to Support the Initiatives of States Countering Piracy off the Coast of Somalia (hereafter, The Trust Fund) currently considers two alternative livelihood projects (UNODC and UNDPA 2011a, b). One is a proposal by the International Labour Organization and the UN Office for Project Services, which is planning to work with Puntland youth to provide professional opportunities outside of piracy. The other one is a project submitted by UNESCO, which aims to create opportunities for employment outside of piracy and promote skills such as conflict resolution or leadership in south central Somalia and Puntland. Both projects basically aim at continuing the work already conducted by the organizations, yet with a strengthened emphasis on counter piracy.

At a 2011 fundraising conference organized by the United Arab Emirates, several further potential projects were discussed. Two of the background papers to the conference made a strong case for concentrating development responses to piracy on the development of port cities, notably Puntland's principal port of Bossasso (Murphy and Saba 2011; Chorin et al. 2011). As argued, port development provides infrastructure for the local economies to prosper as well as significant employment 
opportunities. Murphy and Saba (2011) further stress the importance of connector all weather roads, linking the port to major cities. The building of linking roads would demonstrate the seriousness of the commitment to assist Puntland and could reward villages that stand against piracy. They also suggest complementing economic assistance in developing the pastoral sector in improving the standards of Somali meat for export, long-term and sustainable fisheries programs, the development of water resources as well as mineral extraction.

As Murphy and Saba (2011) highlight, it will be important to coordinate such projects, instead of working in a piecemeal approach. The impact of alternative livelihood projects or economic infrastructure projects for counter-piracy policy will remain indirect. Yet, such approaches can deliver an important reward for local communities if they stand up against piracy and do not offer resources and sanctuary to piracy gangs.

\section{The promises and perils of onshore projects}

As this review documents, some onshore counter-piracy projects have been initiated or are planned. They are, however, only few. Indeed, considering the number of Somali they reach, they are no more than drops in the bucket. In total, the international community spends an estimated US\$3 million for developmentoriented onshore counter-piracy projects. Leaving general aid streams to Somalia aside, this contrasts with the estimated costs of the naval operations of US\$2 billion, and an estimated sum of ransom paid of US\$200 million (Bowden et al 2010).

Phrased otherwise, there remains a strong reluctance to finance onshore counter-piracy programs. This is further underlined if we consider that by mid 2011 The Trust Fund, the main funding vehicle to counter piracy, has not sponsored a single onshore, development-oriented project (UNODC and UNDPA 2011a,b). The Trust Fund prioritizes the sponsoring of projects which rely on a security and law enforcement approach and increase state capacities. Several alternative projects have been so far proposed to the Trust Fund, including projects addressed to improving the fishing sector, community-based prevention projects or capacity building in ports. Yet, out of nine projects, only the two proposals discussed above have been generally accepted but are still being "held" for further clarifications (UNODC and UNDPA 2011a,b).

What are the reasons for the few programs and the reluctance to invest in onshore counter-piracy projects? A number of major reasons can be identified. Below I discuss several of them clustered into five types of problems: (1) knowledge problems, (2) implementation problems, (3) the counterintuitive consequences, (4) tensions towards other parts of counter-piracy strategy, and (5) the securitization of aid. ${ }^{7}$

\footnotetext{
7 The following observations are based on a series of interviews conducted in Nairobi, Kenya in September 2010, interviews conducted in London in 2011, and a range of personal communications conducted in 2011.
} 


\subsection{Knowledge problems}

By knowledge or cognitive problems, I refer to problems that can be located in the broader discourses of the international community on how to cope with phenomena such as the failed state problematique or more distinct threats such as piracy. To start with, there is a general reluctance within the international donor community to fund preventive projects. This is not only a Somali problem, but a phenomenon that can be observed across post-conflict and crisis prevention work. ${ }^{8}$ Secondly, this reluctance is fed by an ongoing lack of knowledge of how to conduct preventive programs. ${ }^{9}$ Arguably much of aid, development and state-building projects have failed so far to achieve the promised outcomes, and this is even more the case in programs related to the prevention of organized crime, local violence, or DDR. Thirdly, there is also the more Somalia specific attitude that the international community should not intervene in Somalia directly, but should act from a distance. This is not the least because of the international trauma caused by the failures of 1990s intervention in Somalia and more specifically the Black Hawk Down trauma. ${ }^{10}$ Investing in onshore measures in Somalia requires close proximity to Somalia actors, partnerships, a direct form of engagement and deep immersion and commitment on the village level.

\subsection{General implementation problems}

A second linked set of problems relates to the difficulties of organizing and implementing projects in Somalia. This starts with basic security concerns, which has forced many international NGO's to pull out of Somalia in the recent years. This is notably the case in the piracy-infected areas of Puntland and Southern Somalia, in which there is a high personal risk for aid workers. But it is also related to very practical implementation problems, such as how to transfer money and equipment into certain Somali areas or how to communicate with local teams effectively. Secondly, there is a high distrust in potential Somali cooperation partners. This distrust is fed by concerns of corruption, the clandestine system, or organizational structures misfitting Western bureaucratic structures, the perceived lack of accountability and control over how funding is used, and last, but not least, concerns about the complicity of many organizations (including governmental) in piracy. Provincial corruption remains one of the main problems.

\subsection{Potential counterintuitive consequences}

A third set of problems that can be identified are concerns over the counterintuitive consequences of onshore counter-piracy programs. Phrased otherwise, projects may do more harm than good. These concerns are, firstly, fed by the meanwhile established fact that some of the fishing equipment provided by international donors has been used in piracy operations. Since one of the areas of work of alternative livelihood projects is in fishery, there is the ongoing concern that the skills achieved

\footnotetext{
${ }^{8}$ See, e.g., de Soto, Alvaro, and del Castillo (1994)

${ }^{9}$ For a discussion of such knowledge problems, see among others Woodward (2007) and Paris (2010).

${ }^{10}$ See, e.g., the discussion in Bryden and Brickhill (2010) and Menkhaus (2009).
} 
in vocational maritime training might be used to participate in piracy, or the donated equipment is either directly used, or robbed and used in piracy. Secondly, there are ongoing concerns over radical Islamism. One should not forget that the main concern of many security actors in Somalia is that the country might become a safe haven for Islamic terrorism, a second Afghanistan. Relying on religious leaders for conducting awareness campaigns, inevitably strengthens the status of Islam in Somalia. Strengthening religion, leads in the mind-set of some security actors to concerns over fundamentalism and terrorism.

\subsection{Tensions between law enforcement and development}

The reviewed onshore counter-piracy programs have, moreover, some obvious tensions to the law enforcement model of countering piracy. Firstly, reintegration and rehabilitation projects are a de facto reward for piracy activity. Former pirates, many of whom which will receive amnesty, are presented with opportunities (including education or grants) that the majority of Somali youth do not have, or only achieve under more difficult circumstances. Hence, re-education and reintegration programs potentially undermine the deterrent of facing a life in prison.

Secondly, another tension relates to fishing as one of the areas of onshore projects. One of the key problems of the maritime counter-piracy patrol system is how to distinguish between a pirate operation and an "innocent" fishing tour. Evidence is often problematic since, for instance, also fishermen tend to carry weapons for self-protection. Indeed in the past, incidents have been reported that fishermen could have been harmed by the navies patrolling the Gulf of Aden. The 2009 NCA survey suggests that these reports have led fishermen to stay on land. For the navies, it is in their general interest to have as few potentially suspicious vessels in the sea as possible. From the development perspective, it is the opposite - it is to have as many fishermen out on the sea as possible on whatever vessel.

\subsection{The securitization of aid}

A fifth set of problems relates to the attitude within the development community working for Somalia. Since piracy is perceived as a security problem (and indeed addressed primarily by security actors) and since there is the ongoing belief that development and security concerns are better kept separate, there is a major gap or disconnect between counter-piracy and development strategies. Firstly, there are ongoing concerns, often dubbed as the "securitization of aid" that short-term security thinking and priorities override development objectives, and that security-related considerations in humanitarian or development projects undermine the status of aid agencies as neutral actors. ${ }^{11}$ Secondly, major parts of the development community, notably those that worked in Somalia for many years, doubt that piracy should be a top priority issue. As a UNDP representative put it in an interview "Once the pirates are gone and with them the foreign navies, we [UNDP] will still be here."12 From a development

\footnotetext{
${ }^{11}$ For a discussion of the tense relationship between security and development actors see Abrahamsen (2005), Chandler (2007), and Youngs (2008).

${ }^{12}$ Author interview with UNDP Somalia representative, Nairobi, Kenya, September 2010.
} 
perspective, piracy might be indeed seen as a relatively marginal problem. Piracy primarily exacerbates the level of insecurity in some villages, yet it is a problem that does not compare with the reach of the food and shelter crisis, the problem of weak infrastructures, poverty, or the ongoing war in the south of the country.

\section{Conclusion: strengthening onshore preventive projects}

Taken together these concerns, problems, and risks provide the major reasons for the reluctance to engage and invest in onshore counter-piracy projects. While it will remain important to be aware about these issues, it does not imply to disengage from onshore programs. Onshore programs are a core and crucial component of counter-piracy. So far, onshore developmental projects remain weakly coordinated and dispersed. A major issue will be to rethink how such projects might be better coordinated. This concerns the relationship between multilateral funding through The Trust Fund and bilateral funding; it concerns the question of which working group of the contact group will coordinate development-oriented projects, but also, maybe most fundamentally, it is an issue of the relationship between counter-piracy policy and the general aid and development efforts in Somalia. So far, counter-piracy and development policy streams are largely disconnected.

Overall, it remains important to recognize that a large portion of the Somali population is not on the side of the pirates or supports them only because they are "necessary evils." Indeed, the 2009 NCA survey found that $95 \%$ of the respondents from coastal towns oppose piracy. Moreover, the example of the town of Eyl, which used to be one the main pirate nests, but, not least because of the projects reviewed above, has not been used as a pirate base for roughly a year now, is a success case to keep in mind. For villages, piracy activity brings, to some degree, business into town. There are economic benefits from piracy for some. Yet, since pirates pay higher prices for common goods, there is also a large array of economic losers that suffer from piracy-induced inflation. Moreover, piracy activity also brings a significant level of insecurity and disorder to villages. Pirates reinforce local insecurity through aggressive behavior, interpirate violence and the proliferation of small arms. They increase the popularity of khat and alcohol consumption as well as prostitution in villages. Several villages have started to organize initiatives to do something against piracy locally. It will be in the interest of the international community to support these local initiatives, assist them in driving pirates out of their villages and towns, and offer them rewards for doing so.

Piracy will, however, remain an important source of income for many members of the Somali society. It might be cynical, but piracy is not only, as we nowadays frequently hear, a "business model", it is also a development model. Of course, not all of the millions of ransom in dollars are invested in the Somali economy. As for instance Jay Bahadur (2011) reports, much of the ransom money is invested in consumption goods, such as, guns, khat, cars, or alcohol, imported from Kenya or Ethiopia. Some of the ransom money might also flow to foreign countries. Some of it is reinvested in piracy operations. Yet, the same time do we have reports of ransom benefiting local communities and clans, being invested in houses, education, or even infrastructure such as health services. While the development benefits of the influx of ransom money are few, maybe too few, piracy means development for some. If the 
international community cannot prevent piracy as such, it should seek an answer to the question of how piracy ransom can lead to real investments in Somalia, instead of insecurity and crime. Perhaps what is needed is the "orderly pirate." That is, the pirate who does not invest his share of ransom money in guns, khat, alcohol, prostitution, or cars but invests it in the Somali public infrastructure, in contributing to housing, streets, schools, and education. Turning pirates into good (pirate) citizens might be the true challenge of onshore counter-piracy programs. It might, however, also imply that Somalia is to become more of a "pirate state" than it is already.

Acknowledgements I am grateful to two anonymous reviewers for the comments on a previous draft and to Jan Stockbruegger for the research assistance. Research for this article has benefitted from a grant by the University of Duisburg-Essen and a grant by the Leverhulme Trust Fund.

\section{References}

Abdi A (2011a) Reformed pirates complete polytechnic training, SomaliaReport, 17.3.2011, http://www. somaliareport.com/index.php/post/314/Reformed_Pirates_Complete_Polytechnic_Training. Accessed 29 September 2011

Abdi A (2011b) An interview with a former pirate. SomaliaReport, 18.3.2011. http://www.somaliareport. com/index.php/post/329/An_Interview_With_A_Former_Pirate. Accessed 30 September 2011.

Abrahamsen R (2005) Blair's Africa: the politics of securitization and fear. Alternatives: Global, Local, Political 30:55-80

Acacia Consultants, Norwegian Church Aid (2010) Norwegian Church Aid Programme Evaluation Report. Somalia programme activities in Gedo, Puntland and Mogadishu. Acacia Consultants, Nairobi

Bahadur J (2011) Deadly waters. Inside the hidden world of Somalia's pirates. Profile Books, London

Bowden A, Kaija H, Eamon A, Charles M, Andrew L (2010) The economic cost of maritime piracy. One Earth Future Foundation working paper, December 2010. One Earth Future Foundation, Louisville

Bryden M, Brickhill J (2010) Disarming Somalia: lessons in stabilisation from a collapsed state. Confl Secur Dev 10(2):239-262

Bueger C (2012) Responses to contemporary piracy: disentangling the organizational field, in press

Bueger C, Stockbruegger J (2012) Security communities, alliances and macrosecuritization: The Practices of counter-piracy governance. In: Michael JS, Mark TN, Carlson JD (eds) Piracy and maritime governance, forthcoming. Routledge, London

Bueger C, Stockbruegger J, Werthes S (2011) Pirates, fishermen and peacebuilding-options for a sustainable counter-piracy strategy in Somalia. Contemporary Security Policy 32(2):356-381

Chandler D (2007) The security-development nexus and the rise of 'anti-foreign policy'. J Int Relat Dev 10 (4):362-386

Chorin E, Dorothy M, Ritzenthaler R (2011) A case for industry involvement in onshore development. Briefing paper for the conference global challenges, regional responses: forging a common approach to maritime piracy, Dubai, April 2011. http://counterpiracy.ae/background_papers.html. Accessed 2 October 2011.

de Soto A, del Castillo G (1994) Obstacles to peacebuilding. Foreign Policy 94:69-83

GaroweOnline (2011) Somalia anti-piracy campaign begins today in Puntland. http://www.garoweonline. com/artman2/publish/Somalia_27/Somalia_Anti-piracy_campaign_begins_today_in_Puntland_ printer.shtml. Accessed 30 September 2011.

Geiss R, Petrig A (2011) Piracy and armed robbery at sea: the legal framework for counter-piracy operations in Somalia and the Gulf of Aden. Oxford University Press, Oxford

Hastings JV (2009) Geographies of state failure and sophistication in maritime piracy hijackings. Political Geogr 28(4):213-223

IMO (2011). Djibouti Code of Conduct. http://www.imo.org/OurWork/Security/PIU/Pages/DCoC.aspx. Accessed 4 October 2011.

Knight WA (2008) Disarmament, demobilization, and reintegration and post-conflict peacebuilding in Africa: an overview. Afr Secur 1(1):24-52 
Knopf J (2010) The fourth wave in deterrence research. Contemp Secur Policy 31(1):1-33

Kraska J (2011) Contemporary maritime piracy: international law, strategy, and diplomacy at sea. Praeger Publishers, Santa Barbara

Menkhaus K (2009) Somalia: they created a desert and called it peace(building). Rev Afr Polit Econ 36 (120):223-233

Murphy MN, Saba J (2011) Countering piracy: the potential of onshore development, briefing paper for the conference global challenges, regional responses: forging a common approach to maritime piracy, Dubai, April 2011. http://counterpiracy.ae/background papers.html. Accessed 2 October 2011.

NATO (2010) NATO commander hosts Nugal authorities off Eyl, NATO News Release SNMG2 2010/1, April 29 2010. http://www.manw.nato.int/pdf/Press\%20Releases\%202010/Jan\%20-\%20May\% 202010/20100424-NATO\%20Commander\%20meets\%20Nugaal\%20authorities\%20of\%20Eyl-NR16. pdf. Accessed 29 September 2011.

Norwegian Church Aid (NCA) (2010) Counter piracy leaflet. On file with the author.

Paris R (2010) Saving liberal peacebuilding. Rev Int Stud 36(2):337-365

Peacelink (2011) Current activities. http://peacelinksomalia.org/Actitvities.html. Accessed 29 September 2011.

Percy S, Shortland A (2009) The pirates of Somalia: the coastguards of anarchy. CEDI Working Paper 09 (09)

Percy S, Shortland A (2011) The business of piracy in Somalia. DIW Discussion Papers 2011(1033)

Rashid A (2009) Assessment report Puntland counter-piracy survey June/July 2009. Norwegian Church Aid. www.changemaker.no/PageFiles/793/Final\%2520Assessment\%2520Report.doc. Accessed 29 September 2011.

Security Sector Reform Resource Centre (SSRRC) (2010) Somalia's autonomous regions seek international assistance for increased SSR. http://www.ssrresourcecentre.org/2010/05/25/somalias-autonomousregions-already-undergoing-ssr-seek-international-assistance/. Accessed 28.09.2011.

NATO Shipping Centre (2011) NATO Broadcast. http://www.shipping.nato.int/operations/OS/Pages/Nato Broadcast.aspx. Accessed 29 September 2011.

U.S. Airforce. 2007. Airmen drop 80,000 leaflets over Afghanistan. http://www.af.mil/news/story.asp? id $=123054828$. Accessed 25 May 2011.

UNODC and UNDPA (2011a) Trust Fund to support the initiatives of states countering piracy off the coast of Somalia. Annual Report 2010. April 2011. Vienna: UNODC

UNODC and UNDPA (2011b) Trust Fund to support the initiatives of states countering piracy off the coast of Somalia. Contributions and Projects. September 2011. Vienna: UNODC.

Vagg J (1995) Rough seas? Contemporary piracy in South East Asia. Br J Criminol 35(1):63-80

Woodward SL (2007) Do the root causes of civil war matter? On using knowledge to improve peacebuilding interventions. Journal of Intervention and Statebuilding 1(2):143-170

Youngs R (2008) Fusing security and development: just another Euro-platitude? Journal of European Integration 30(3):419-437 